\title{
Dinde Reform
}

\section{Hüseyin ATAY}

Prof. Dr., Ankara Üniversitesi Ilâhiyat Fakültesi

Reform in the Religion. Religion is in itself formed by some fundamental bases which have permanent and perennial characters. These are the common denominators shared by the believers living at different times and places. However, in addition to these unvariables there are some principles which vary according to conditions the believers live in. In Islamic literature there are such concepts as tecdid, ictihad which are employed to apply these principles to various conditions. In this context, one of the most remarkable trends in recent times is to discuss the innovation or reform in Islamic thought. The article here is putting forward another approach to the nature, structure and method of this innovation.

Key Words: Tecdid, İctihad, Reform, Religious Thought.

\section{Kavramsal Çerçeve}

\section{1a. Reform}

Reform kavramı, 'form' kelimesinden türetilmiş bir kelimedir. Form (forme Fr.): Şekil, biçim, kalıp, örnek; anlaşılır, kavranılır yapı; bir özün, tözün, cevherin bir nesnenin dı̧̧ özelliği. Form (forme), bir şeye kendi doğasına göre varlık, biçim, özellik verme. Örneğin, demokrasi, otokrasi (idarenin tek kişide olması) gibi. Form (forme); tertiple düzenleme, bir araya 
getirme yöntemi. İçerikten, esastan ayrı usul; herhangi bir maddeyi, belli bir biçime koyma; bir şeyin unsurlarını bir arada tutma ilkesi.

Form (forme): Biçimlendirmek, şekillendirmek, olmak; imal etmek, yapmak, düzenlemek; öğretim, eğitim, deneyimle biçimlendirmek, özellik kazandırmak, davranış geliştirmek, tertip etmek.'

Bir nesnenin özelliği özünden ayrıdır. Bu, nitelik ile nitelenen yani sıfat ile mevsufun ayrı olması gibidir. Form kelimesini felsefede ilk kullananın Aristo olduğu biliniyor. Aristo tabiî ki form kelimesinin Yunancası olan 'eidos' kelimesini kulland, ancak $^{2}$ her zaman olduğu gibi terimsel (istılâhî) kavramlar temel anlamlarını sözcüklere dayandırırlar. Aristo bir nesnenin varlı̆̆ını iki şekilde anlatır: Biri onun özü (heyûlâ, hile); diğeri de biçimi, şekli. ${ }^{3}$

Burada dikkate alınması gereken husus filozofun, form (biçim, şekil) ile heyûlâyı, yani biçimlenen maddeyi birbirinden ayırmasıdır. Madde, öz, cevher (heyûlâ) değişmez, ama biçimi, şekli değişir. Özün biçim ve şekil aldığı her biçimin ve şeklin içinde değişmeden süregelmesi, devam etmesidir.

Reform (reformer Fr.): Yanlışları, eksiklikleri gidererek daha iyi yapmak, düzeltmek, yolsuzlukları, ırza tecâvüz etmeleri, kötülükleri, durdurup engelleyerek daha iyisini yapmak, kişiyi ikna ederek veya zorla kötü işlerini bıraktırıp iyi davranmasını sağlamak; şekil ve suretini değiştirip iyileştirmek, 1slah, tanzim ve tertip etmek, iyileştirmek; bozulmamış ilk durumuna getirmek, muzır (zararlı) bir usulü lağvetmek (kaldırmak, feshetmek, yürürlükten kaldırmak) ve yeniden teşkil etmek (Büyük R); dinde iyileştirmek, tenkih etmek, zararlı şeyleri ayıklamak, (Allah'a) dönmek, yapılan yanlıştan dönmek.

XIX. asırda Yahudiliğe bir biçim vermekle, tarihî Yahudiliğe akılcı düşünceyi ve geleneksel dini merasimleri sıkı göreneğinin gerekmezliğini normalleştirmek; Hıristiyanlık dininde de Protestanlığın mucidi olan Luther tarafından (1517) îcad olunan tadilat, değişiklik, yeniden düzeltim, dinde düzeltim; su-i istimalin izalesi; yeni oluşum biçimi, dış görünüm.

Reformation: Islah, din ıslahı, yanlıştan dönme; nefis ıslahı, daha iyi duruma koyma veya girme; kötü gidişsten dönüş; tövbe; 16. Yüzyılda dinî ıslahat; 16. Yüzyılda Protestan Kilisesisinin tesiri ile neticelenen dinsel devrim; Roma Katolik Kilisesinin islahı. ${ }^{4}$

Reform kelimesi hakkında buraya aldığımız anlam ve kavramların hangisi, dinde reform olunca dini kökünden, temelinden değiştirme vardır?;

${ }^{1}$ Bütün bu tanım ve anlamları İngilizce-Türkçe (eski ve yeni), İngilizce-Arapça, İngilizceİngilizce; Fransızca, Türkçe (eskj ve yeni) ve felsefí sözlüklerden seçip derledik.

2 D. D.Rumes, Dictionary of Philosophy (New Jersy, 1961) 21, 110

${ }^{3}$ Hüseyin ATAY. Ibn Sinâ' da Varlık Nazariyesi (Ankara, 1983) 96

${ }^{4}$ Birinci dipnot. 
bu, dinde reforma düşman kesilip gereksiz yere konuyu saptırmaktan başka bir davranış değildir.

\section{1b. Tecdid}

Arapça'da 'tecdîd' kelimesi, Türkçe'de kullanılan ve yenileştirme, yeni yapma, tazeletme anlamlarına gelmektedir. Tecdid kelimesinin türetildiği kök 'c-d-d' olup üç temel anlamı olduğu söylenmektedir: Büyüklük, azamet, yücelik. İkincisi haz, nasip, hisse, zenginlik; üçüncüsü, kesmek olup kelimede asıl olan mana budur. Örneğin 'Sevbun cedîd' (yeni elbise) dendiği zaman, sanki terzi onu şimdi kesip biçti, anlamına gelir. Buna dayanarak herhangi bir şeyin üzerinden gün geçmemişse ona yeni, şimdiki şey denir. Bundan dolayı gece ile gündüze de iki yenileşen şey 'cedîdeyn' denmesi, bir biri ardından her gelişleri, yeniden oluşuyor. ${ }^{5}$ Cedîd : Yeni sıfatından tecdîd, yeniletme, yeni yapma, yeniden yapmak, eskiyi bırakıp yeni bir şey almak, eskiyi düzeltip yeni duruma, biçime, şekle koymak; sağlamlaştırmak, yeni elbise giymek; onarmak, tamir etmek, güçlendirmek. Yeni demek, öncekilerden farklı olan bir şey olduğuna göre, yenide bir başkalığın olması, yeninin içerdiği temel bir anlamdır. Tecdîd kelimesinin iki temel anlamı olduğunu görüyoruz: Birisi yenilemek, eski bir şeyi yeniletmek, yeni duruma getirmek; şimdi nasıl olması gerekiyorsa öyle yapmak, ona yeni bir biçim ve şekil vermek. Bunda yenilenen şeyin özünü, mahiyetini, maddesini yok etmek ortadan kaldırmak anlamı yoktur; sadece yönlendirme, biçimlendirme anlamı vardır.

İkinci anlamı yeni bir şeyi ortaya koymak, olmayan bir şeyi icâd etmek, eskiden olmayan bir şeyi üretmek, yeniden yapmak, hiç yok iken yeni bir şeyi varlık dünyasına çıkarmak.

Reform kelimesinin Türkçemize ne zaman girdiğini tespit etmek zor olmasına zor; ancak Avrupalılaşma sürecinin başlangıç tarihi olarak kabul ettiğim ilk Deniz Mühendislik Okulu'nun kuruluşu olan 1774 den ve 1839'daki Tanzimat Fermanından sonra kullanımının ağırlık kazandığını düşünüyorum. Çünkü Tanzimat'ta Türk eğitimine ve idaresine yeni düzenlemeler getirildi. Kuşkusuz bunların içinde müslümanların hoşnut olmadıkları, dînî hükümlere aykırı olanlar da vardı ise de, bunlar devletin idaresini ilgilendiriyordu. Medrese de bu yeniliklerden pek uzak kalamadı. Kadı yetiştirmek üzere medreseye bağlı, ancak medrese dışı yeni bir programla 1854 'de yeni bir okul açma zorunda kaldı. O zaman dinde bir yenileşmeyc, reforma ihtiyaç olduğu, yapılan reformların estirdiği hava neticesinde ilgili kesimlerin zihinlerinde çakmaya başlamış olmalıydı. Bütün bu yeniliklere medrese kesimi ve ulema alınmadığı için, onlar bu reformların dışında bırakılmışlardı. Bir gün kendi başlarına da bir yenilenme, reform belasının geleceğini düşünmeye ve ondan ürkmeğe başlamışlardı. Devleti elinde tutan yenilikçiler, artık dinde de bir reform ve yenilenme hareketinin

\footnotetext{
${ }^{5}$ İbn Fâris, Mu'cemu Mekâyis'el-Luğa, Mısır 1366 (h)/1946 (m) 1/406,409.
} 
başlatılması gerektiğini telaffuz etmeğe ve dillendirmeğe başladıklarında, dînî kesim buna karşı çıktı ve dini tahrif etme, değiştirme, dinsizlik olarak suçlamaya koyuldular. Şimdi de düşünmeden, araştırmadan aynı tepkiyi sürdürüyorlar.

Dediğimiz gibi reforma karşı çıkmanın birinci nedeni, kelimenin müslüman olmayan milletlerin dilinden gelmesi, ikinci neden de bunu medreseye karşı olan kesimin kullanmasıdır. Diğer sebepler, yan sebeplerdir. Oysa reform kelimesinin karşıllı̆ 1 olan 'tecdîd' kelimesi İslâm din kitaplarında, Hz. Peygamber'in sözlerinde-uydurma veya zayıf olsa dabulunmakta. Bazı âlimleri müceddit (yenilikçi) olma unvanları ile sıraya koyup övmekte oldukları bir gelenek de oluşturmuşlardı. 1940-1950'li ylllarda eski medrese âlimlerinden birisi bu 'müceddid' mertebesine ulaşma arzusunu; Hz. Peygamber'in bir sünnetini yapmaya çalışmanın, insanı mücedditler mertebesine çıkaracağını söyleyerek kendisini $\mathrm{Hz}$. Peygamber'in sünneti saydıkları sakal bırakmaya vererek sergilemişti. Dediğim gibi, reforma karşı çıkanlar, haklılıklarını ispatlamak uğruna, tuttular tecdide, yenileşmeye de karşı çıkmaya başlamışlardır. On beş sene önce 'Íslâm'da Yenilenmenin Kurallari' adıyla bir eser yazdım. Fakültedeki meslekdaş dostlarım, eserin adını değiştirmemi tavsiye etmişlerdi. Kitap üç yüz küsür sayfa ve şu anda basıma hazırdır. Çünkü din adamları ve halk, dini yeniden anlamayı hâlâ dinsizlik kabul ediyor. Elli sene önce başlattı̆̆ım 'yenilenme', dini yeniden anlama anlaminda 'tecdîd' kelimesini, onu dinsizlik sayanlar tarafından telaffuz etmeye çalışmalarını bir gelişme saymalı mı? Çünkü bir kavramın gereğini yapmak için önce onu dillendirerek benimsenmesini yaymak gerekir.

Öncelikle şunu söylemek yerinde olacaktır. Herhangi bir alanda yenilik yapacak yeni bir şey ortaya koyacak, yeni anlamlar, buluşlar üretecek o alanın insanıdır. Dinde reformu, din bilginleri, müçtehitler; bilimde reformu ise filozoflar, düşünürler yapar.

\section{1c. Bid'at}

Yenilemenin, tecdîdin, reformun İslâm fikir tarihindeki olayına 'bid'at' denmiştir. Bid'at, yepyeni bir şey ortaya koymaktır ki, bu kelimeden $i b d a$ ' kelimesi türer ve örneği olmayan bir şeyi yapmak, icat etmek, yaratmak demektir. Bid'at yeni bir model, biçim, tarz ortaya koymak anlamındadır. Arap putperestleri de Hz. Peygamber'i ve Kur'ân'ı yermek, insanların gözünden düşürmek için değişik ve birbiriyle çelişen tutumlar ortaya koyuyor ve deyimler, söylemler kullanıyorlardı. Bazen Kur'an'a eski masallar der, bazen de $\mathrm{Hz}$. Muhammed'e yenilikçi, bid'atçı, diyerek eskiye karşı yeni bir oluşumu kurduğu için gözden düşürmeğe çalışırlardı. Kur'ân bu itiraz ve yermelere cevap verirdi. Buna Kur'ân şu yanıtı vermektedir:

"De ki: 'Ben, elçilerin içinde ilk (bid'atçı) değilim. Bana ve size ne yapılacağını bilemem; ben sadece bana vahyolunana ,uyuyorum."(46/9). 
Kur'ân'ın kullandığı "bid' " kelimesinin sözlük anlamında şunlar var: yapılan ilk şey, örneksiz, öncesiz bir tarz, yeniden olan nesne; yeni model, olağanüstü bir şey, yenilik heveslisi, yenilik özentisi olma; bir niteliğin en son gayesine ulaşma ki, bilgin olma, yiğit olma, şerefli, onurlu olmada gayeye varma. Bunun için Kur'ân'ın Türkçe çevirilerinde bu kelimeye "ilk", "ilki" (ben de bunu yeğledim) diyen ile "türedi" (Hamdi Yazır), diyenler olduğu gibi, Ingilizce çevirilerde de aynı birbirlerine yakın 'bid' kelimesinin içeriğine giren kelimeler kullanılmıştır.

Dikkat edilecek olursa âyette üç cümle yer allyor. Birinci cümlede Peygamber'in ilk olmadığı ifade edilirken, geçmiş peygamberler ne yaptıysa, kendisi de aynısını yapıyor. Peygamber olmak yeni bir şey değil; peygamberler toplumu, toplumun dinini sslahla uğraşmışlar, ben de (Muhammed) aynı şeyi yapiyorum. Bunda şaşılacak bir şey yok. Ortaya koyduğum şeyleri ün kazanmak ve şöhret yapmak, yenilik özentisi olarak yapmıyorum. İkinci cümle, birinciyi açıklıyor. Böyle yapmakla ve demekle beraber benim ve sizin başınıza neler geleceğini bilirim, davasında da olmadı ̆̆ım için size bir otorite kurmak niyetinde olmadığımı ifade ediyorum. Üçüncü cümle ise, bu söylediklerimde ve yaptıklarımda kendime ulaşan bir bilgiye göre yapıyorum; herkesin bu bilgiyi açıkça bilme imkanı olduğu için doğrusunun, yanlışının, ne olduğunu bilebileceklerini ifade ediyor. Bu sübjektif, insanın içinde ve dünyasında kalan bir bilgi olmayıp herkesin görüp değerlendireceği objektif bir durumun bilgisi olduğunu ortaya koyuyor.

Putperestler Hz. Peygamber'i yeni bir şey ortaya koymakla, bid'atçılıkla nitelemelerinde kendi geleneklerine göre haklı idiler. Çünkü $\mathrm{Hz}$. Muhammed onlara yeni bir biçim, deneyim, eylem, yeni bir oluşum getiriyordu. Bu onlara göre yeni bir şey idiyse de aslında o ezelî, tarihin derinliklerinden süzülụ̈p gelen bir gerçeğin kendi dillerine göre anlatımı idi. Bunun için $\mathrm{Hz}$. Muhammed bir bid'atçı, yenilik düşkünü değildi. Ancak gelenekçi, eskicilik düşkünü de değildi. Ne olursa olsun, sadece yenilik olsun diye, değişik bir şey ortaya konması davasında değildi. O, gerçeği, gerçek olanı tekrar gündeme getiriyor; bu ortaya koyuştaki özellik ve yenilik onun anlatım tarzında ve kolayca uygulanabilecek biçimde ve şekilde doğru olmasında idi. İşte geleneklere, törelere bilinçsizce ve körükörüne uyanlar, bu kadar yeniliği bile kavrayamadıklarından tümden yeniliğe, yeni tarz bir anlatıma karşı çıkıyorlardı. İlk müslümanların içinde, tarih boyunca ve günümüzde benzer gelenekçiler ve eskiye düşkün, yeniliğe düşman olanlar bulunagelmiştir. Hele aşağı yukarı üç asırdan beri yenilik (bid'at) düşmanları Islam toplumlarına hakim durumda olduklarından, İslâm milletleri ve toplumları dünyanın kalkınmış milletlerinin çok gerisinde kalmanın sıkıntısını çekiyorlar. İslâm dünyasının geri kalmışlıktan birey, toplum ve devlet olarak çektikleri sıkıntının nereden kaynaklandığını araştırmıyor, bilmiyor; çünkü düşünmeğe, fikir üretmeğe, yeni bir söyleme karşı amansızca düşmanlık yapıyorlar. 


\section{1d. İçtihat}

İslâm'da reform yapmaya içtihat yapmak denir. Bundan dolayı her müçtehit reformcudur. İçtihat demek, 'dinin ana kaynaklarına dayanarak, onlardan hareket ederek yeni bir hüküm çıkarmak ve yeni bir anlayış ortaya koymaktır'. İslâm'ın ana kaynakları akıl ve Kur'ân'dır. Hz. Peygamber'in sözleri ve işleri (Sünnet); bu iki kaynağı kullanmanın örnekleri, yöntemi ve bu iki kaynağın yorumu ve açıklaması, tefsiridir. Bunlar zamana, mekâna, bireye ve topluma göre değişir. Hz. Peygamber'in örnek olması, O'nun yaptığının aynısını, tıpkısını yapmak, kopya etmek, taklit etmek anlamında olmayıp insanların yararlarını gözeterek, hedef alarak örnekler üretmektir. Tek ve basit bir örnekle bu şu demektir:

Günümüz Islâm dünyasında içtihat konusunda üç türlü görüş vardır:

a. Bazı kimselere göre içtihada hiç gerek yoktur. Eski müçtehitlerin sözlerini anlayıp uygulamak yeter. Görüldüğü gibi bunlar İslâm’ı ve dünyayı anlamamış, dưşünmeye karşı bağnaz kişilerdir. Bu gibileri siyasette, devleti idarede de görmekteyiz.

b. Bazı kimseler ise geçmiş müçtehitlerin yaptıkları içtihatlar olduğu gibi kalıp uygulansın, onların içtihatları bulunmayan konularda yeni içtihat yapılmasını doğru ve gerekli görürler.

c. Üçüncü tür içtihat görüşü, geçmiş müçtehitlerin içtihat yaptıkları konularda da yeniden içtihat yapmak doğru ve gerekli olduğu gibi, yepyeni olaylar hakkında da yeni içtihatlar yaparak hüküm vermek gerekmektedir. İçtihat hiç kimseyi bağlamaz. Buna 'içtihat mülzim değildir' denir. Bir müçtehit kendi içtihatına uymak mecburiyetinde de değildir. Çünkü o da içtihatını değiştirebilir.

Geçmişteki müçtehitlerin koydukları içtihat kuralları, kendi zamanlarındaki bilgi düzeyine, insanların anlayış ve şartlarına, ihtiyaçlarına göre olduğu için, onları tekrar gözden geçirerek değiştirmek, günümüzün bilgi düzeyine ve şartlarına göre yepyeni kurallar koyarak içtihat yapmak gerekmektedir. Geçmişte kullanılan kuralların geçerli olanlarını reddetmeye kuşkukusuz ilmî açıdan da imkân bulunmayacağından, onlar da kullanılabilir.

Reform değiştirmek olmayıp yanlışları düzeltmek, ıslah etmek, salih amel işlemek, yararı bir iş yapmaktır. Reform ve içtihat yapmak, kayıtsız ve şartsız düşünmekle olur. Kötü yönde değiştirmeye ve bozmaya reform denmez; ona deform denir.

Reform kelimesini kullanmamın gerektiğine inanıyorum. Arapça'da kullanılan 'tecdîd' ve Türkçe'de kullanılan 'yenileme' ile, gene Türkçe'de kullanılan 'yenilikçilik' arasında fark, dindar ile dincilik, lâik ile laikçilik arasındaki fark gibidir. Yenileme, bir şeyi, daha iyi bir duruma getirme, yenilikçilik ise herhangi bir yeni şey yapma, eskiden olmayan nesne yapma, bu doğru da olabilir yanlış da. Yenilemek ise eskiden olan bir şeyi güzelleştirme, daha iyi yapma anlamını ifâde eder. Bid'at kelimesi aslında 
kök olarak yeni bir şey ortaya koymak olduğu için iyisi ve kötüsü olursa da bid'atin kökünde gene de iyiye yönelik bir kavram vardır. Bunun için edebiyatta ve güzel sanatlarda 'bedî̀' kelimesi, güzel bir şey ortaya koyma anlamında kullanılmıştır. yaratanı.

'Yerin ve göklerin bedî̀' (2/117); yani örneksiz. en güzel biçimde

$\mathrm{Ne}$ var ki reform kelimesinde de asıl anlam güzel yapmak, iyi yapmak, güzelleştirmek, iyileştirmektir. Reform kavramında kötü, çirkin bozuk anlamı yoktur. Ben burada reform kelimesi kullanıyorum diye, onun kullanıldığı dilde olmayan, kendimce bir mana vermediğimi kanıtlamak için günlük dilde kullanılan küçük İngilizce sözlüğün tanımını, İngilizce olarak buraya almak istiyorum:

\section{Reform:}

1. To make better, by removing abuses (Yanlış kullanışları gidererek daha iyi yapmak).

2. To improve morally; persuade, or educate to a better life (ahlâkça daha iyi yaşama göre düzeltmek; iknâ' etmek veya eğitmek).

3. To give up sin or error (günahtan veya yanlıştan vazgeçmek, günahı ve yanlışı bırakmak). ${ }^{6}$

Görüyoruz ki reform kelimesi herhangi bir şeyi veya işi yeniden herhangi bir biçimde değiştirmek veya yenilemek olmayıp herhangi bir şeyi veya işi daha iyi yapmaktır. Reformda hem iyi, hem kötü kavramı yoktur. Sadece daha iyi kavramı vardır. Arapça da buna karşılık 'ıslâh' kelimesi kullanılabilir. Tecdîd kelimesi yenileme daha iyi ve güzeli yapma anlamına olursa, reform karşılı̆̆ı olarak kullanılabilir. Türkçe'de yenileme, yeni bir şey yapma anlamına kullanılırsa, reform kelimesinin tam karşılığı olmaz. Ancak yenileme bir şeyi daha iyi yapma anlamında kullanılırsa reform'un tam Türkçe karşılı̆̆ 1 olur. Kur'ân'ı Kerîm bunun için ' sslâh' kelimesini kullanmaktadır. Islâh'ın kökü 'salah'tır. Salah, 'iyilik, yararlılık, iyi olma' dan türeyen ' $ı l a ̂ h$ ' kelimesi daima iyiyi yapma, iyiye göre düzeltme kavramı bütün türemişlerinde içlem bir anlamdır. Bunun için her zaman derim ki Kur'ân'ı Kerîm eskimeyen, her zaman kullanılabilen çok teknik, incelikli kelimeler kullanır.

Reform kelimesinin karşıtı olan 'deform'; şeklini, biçimini bozmak, çirkinleştirmek, deforme etmek, yok etmek, harap etmek demektir. Arapça'da bunun karşılığı olarak 'bid'ât-i seyyie' konulabilir. Anlaşılıyor ki, reform, bozma, kötü biçime koyma, anlamına kullanılmadığının kanıtı olarak deform kelimesinin bulunmasıdır. Reform mutlaka temelde iyi yapma, deform da bozma, kötü yapmadır.

\footnotetext{
${ }^{6}$ Funk and Wagnells, Standard Dictionary, First Signet printing, August, 1980, USA
} 


\section{Reformun Bilgisel Temeli}

Dinler tarihine baktığımız zaman, dinde en son ve en köklü reformu Kur'ân'ın getirdiğini görürüz. Kur'ân'ın anlattı̆̆ı peygamberlerin her biri, bozulan dinde reform yapmış, bundan dolayı da sert, güçlü direnişlerle karşı karşıya kalmışlardır. Bunların en sonuncusu ve köklüsü, Kur'ân'ın dinde yaptığı reformdur.

Kur'an'ın köklü bir reform gerçekleştirmk için yaptığı ilk şey, bilgi anlayışını değiştirmek olmuştur. Kur'ân'ın insana getirdiği yegâne şey bilgi kuramı, yani bilgi teorisi, epistemolojidir ve bu kuramını üç sacayağı üzerine oturtmuştur:

a) Bilgi, b) Yöntem, c) Düşünme.

a.) Kur'ân bilgi elde etmenin kaynaklarını da belirtmiştir.

1) Beş Duyu,

2) Vicdan

"Allah sizi annenizin karnından çıkardığı zaman hiçbir şey bilmiyordunuz. Size kulak, gözler ve gönüller vermiştir."(Nahl, 16/78; Mülk, 67/23).

"Bilmediğin şeyin ardına düşme, Doğrusu kulak, göz ve gönül, işte bunların hepsi, sorumludur."'(İsrâ, 17/36).

3) Hazır bilgi, Kur'ân beş duyunun ve vicdânın dışında bir de başkasının bilgisinden yararlanmayı önermiş, onu da bilgi kaynağı olarak kabul etmiştir. Bu aslında hazır bilgi demektir. Bunun için Kur'ân 'oku!' emriyle başlamıştır. 'Oku' emrinin tümleci(mefulu), gösterilmemiş, belirtilmemiştir. Bunun anlamı 'her şeyi oku!', demektir. Insan neyi okur? Başkasının yazdığını, yazılanları veya daha önce okuyup ezberlediği şeyi okur. Bu, başkasının bilgisinden yararlanmaya emir demektir.

b) Kur'ân'ın getirdiği yöntem, 'tümevarım' yani, cüziyattan külliyata gitme yöntemidir.

"Sözlere kulak verip de en güzeline uyan kullarıma müjde ver. Onları Allah doğru yola eriştirmiştir. İşte onlar özgün akıllılardır."(Zümer, 39/18).

$\mathrm{Bu}$ âyet tümevarım metodunu, yöntemini ortaya koymaktadır. Bu yöntem iyi şeyleri teker teker öğrendikten sonra, aralarında karşılaştırma yapıp en iyisini, en güzelini, en doğrusunu bulup almayı önerir. Bertrand Russell, 'on yedinci asırda, Francis Bacon'ın ortaya attığı ve Aristo'nun ilimde otoritesini yıktığı ilmî metot (yöntem) budur' demiştir. İşte Kur'ân, Aristo'nun otoritesini bu âyetle Bacon'dan bin sene önce, daha yedinci yüzyılın başında yıkmıştı. Bertrand Russell, İslâm felsefesini bilmediği için öyle demiştir.

Tümevarım (endüksiyon, istikra), tekil olguların gözlemlenmesiyle veya olguların tek tek denenerek kaydedilmesiyle, tümü için gerçeklik ve hepsini içine alan tümel ve genel önermelere, ifadelere ulaşmaktır. Bu mantıksal bir işlem ve bir tür akıl yürütme yoludur. 
Bunun tersi olana tümdengelim (dedüksiyon, külliyattan cüziyata gidiş) denir ki, önce tümel, küllî, genel bir kural konur, kanun yapılır; sonra o kural ve kanun tikellere ve bireylere uygulanır.

Tümdengelimle yapılan kanun ve konulan kural, baskıcı, özgürlüğü kısıtlayıcı ve engelleyici olur. Çünkü daha önce bireyler ve tikeller incelenmediği için, onlara uygulamakta çok aksaklıklar meydana gelir. $\mathrm{Bu}$, toplumun bireylerinin durumlarını incelemeden, fildişi kuleler içinde yapılan kanunların başarısızlığına götürür. Bundan dolayı ilmî bir yöntem değildir.

c) Kur'ân düşünmeye çok önem vermiş, düşünmeyen kimseyi 'davar' saymış ve o tür kimselerin başına pislikler, felâketler yağacağını bildirmiştir.

"Beyinleri olup anlamayanlar, gözleri olup görmeyenler, kulakları olup işitmeyenler, işte bunlar davarlar gibidir, belki de daha aşağıdadırlar." (A'râf, 7/179).

"Allah katında canlıların en kötüsü, sağır olanlar, dilsiz olanlar ve düşünmeyenlerdir."(Enfâl, 8/22). $10 / 100)$.

"Allah düşünmeyenlerin üzerine pislik felâketler yağdırır." (Yûnus,

Müslümanlar bilgi kuramının bu sacayağının her bir ayağına, bilgi kaynaklarına, tümevarım yöntemine ve düşünmeye on birinci asra kadar önem verdiler ve onu uyguladilar. Bunun sonucu olarak bir dünya medeniyeti kurdular ve bir dünya felsefesi yaptılar.

Islâm Hukûkunda Hanefîler tümevarım yöntemini kullandılar. Önce olayları inceleyip sonra kitabını yazdılar. Oysa Şafî̀ler tümdengelimi kullandılar. Önce kuralları koydular; sonra onları uygulamaya dâir kitaplar yazdılar. On birinci asra kadar bu iki yöntem kullanıldı. Ayrıca on birinci asırda Haçlı seferleriyle birlikte Doğuya gelen Hıristiyanlardan Müslümanlar tümdengelim (Külliyattan cüziyata gitmek) yöntemini aldılar ve Hıristiyanlar da Müslümanlardan tümevarım yöntemini alarak, bir yöntem mübadelesi yaptılar. Böylece Müslümanlarda tümdengelim yöntemi yaygınlaşıp üstün gelince, ilim durakladı. Buna mukabil Hıristiyanlarda ilmî çalışmalar başladı. Müslümanlar hâlâ tümdengelim yönteminde yanılgıdan yanılgıya, felâketten felâkete düştüklerinin nedenini bilmiyorlar, aramıyorlar; çünkü düşünmüyorlar.

Siz düşünüyor musunuz?

Bugün Türkiye her şeyde, özellikle kânunlarda, kânun yaparken tümdengelim yöntemini kullandığı için, başarıya ulaşamıyor. Bir felâketten daha kötüsüne düşüyor; iflâstan iflâsa gidiyor. Bunun nedeni tümevarım metodunu kullanmamasıdır. Bütün eğitim ezberciliğe, tek şeyi öğretmeye dayanması, tümdengelim yöntemini kullanmanın bir sonucudur. 1774'den beri hâlâ tümevarım yöntemini kullanmayı öğrenemedik. Çünkü uzun yoldur, masraflıdır, çıkar getirisi azdır, fikir ürettiği için zordur. Kânunu fildişi kulesinden yapanlar, uygulamaya koymadan çizerler veya kânun Cumhurbaşkanından döner ya da Anayasa mahkemesinde iptal edilir. 
1774'den beri Türkiye ilmî yöntemi alma niyetinde ve eğilimde olmadan, sâdece teknik bilgiyi hazır olarak taklit etmeye başladı. Bilgi ile yöntemin birbirinden farklı olduğunun ve yöntemde olan geleneksel tümdengelim yönteminin dişında, onun zıttı olan tümevarım yöntemini anlayıp, farkedip özümseyemedi. Onu hiç duymadı. Onu hiç bilemedi demek belki biraz suçlama taşıyabilir. Ancak, görünen odur ki, bütün hükümetleri, idarenin, kânun koyucuların, siyasilerin ve kanun uygulayıcıların iki de bir zihinlerinin ve ayaklarının sürçmesi herkes tarafından görülürken, kınanırken kimse bunun sebebine inmiyor. İşte onun sebebi bilgi kuramı eksikliğidir.

Biz bunu dinde, dini düşüncede reformda ve dindeki bilgi kuramının gereğini gündeme getirip anlatarak uygulamaya koymak çabasını göstermeğe çalışıyoruz. Bilgi kuramı içinde, öncelikle üzerinde durulması gereken Türkçe'de dînî kavramları, düşünceyi geliştirmek için gereken kelimelerin anlamlarını yeniden ele almak, günümüzün anlayışına göre açıklamak ve belirlemek, netleştirmekle insanlara açık seçik, kolayca anlayıp üzerinde düşünebilecekleri önermelere, çıkarımlara ulaşmalarını sağlamaktır. İşte bunun için dinde reform yapmanın ne anlama geldiğini açıklamak gereksinimini gidermeğe çalışacağım.

\section{Yöntemsizlik - Tutarsızlık}

İslâmcı kesimde ilmî olmayan, gerçeğin peşinde olmayan bir tutum şudur: Başkasından gelen bir fikre karşı çıkmak, ona düşman olmak; onun doğru, yanlış olduğuna bakmadan, madem başkasındandır, öyleyse o mutlaka yanlıştır, peşin fikirlilik ve inançla onunla mücadele etmek. Bu zihniyeti İslâm'ın ilk asrında da görüyoruz. Ancak o zaman topluma hakim durumda olmadığı halde, bazı alimlerin öldürülmelerine sebep olmuşlardı. Bir âlim bir fikir veya yeni bir açıklama ortaya attığ soyu sopu araştırılır, bulunamayınca uydurulur; işte Habeşî, Yahûdî, Hıristiyân veya Mecûsî olduğu ileri sürülerek dini yıkmaya çalıştı̆̆ı, mürted olduğu, dinden çıktığı, kafir olduğu, dini inkar ettiği için öldürülmesine fetva verilmiştir. Tarihte ve günümüz Türkiyesinde bu durum, devlet ve rejim düşmanlığı ile gittikçe sertleşmekte değil midir? Ne var ki İslamcı kesimde durum böyle olduğu gibi, solcu kesimde, laikçi kesimde de aynı anlayış hiç eksilmeden sürdürülmekte, karşı kesimin övgüsüne bile razı olunmamakta, düşman gözü ile bakılmaktadır. A grubundan biri B grubundaki bir adamı haklı bir işinden dolayı övse, B grubundakiler, kendi adamlarını hain sayabilmektedir. A grubundakiler ise karşıtlarımı övdügü için kendi gruplarından çıktığına hükmetmektedir. Düşmanlık fikre değil, kaynağına, sahiplerinedir. Bunun için fikre, anlamaya, düşünmeye bakmadan, onun doğru veya yanlış olduğunu tartışmadan, kimin söylediğine bakılarak hangi kesimden olduğu ve geçmişinde kimden yana tavır koyduğu gözönüne getirilir. $\mathrm{O}$ kadar yapıcı çözümler getiren düşünce sahiplerinin cezaya 
çarptırılması veya öldürülmesinden sonra, kim bir daha öyle kurban olmaya cesaret edebilir?

Sözün, düşüncenin kendisine değil, kimin olduğuna bakılır. Tarihte İslâm âlimleri, hele sekiz yüz sene önce yaşamış büyük Kelâm alimi Fahruddîn-i Râzî bile bu tutumu tenkit etmişti. O halde 'kim dedì' değil, 'ne dediǧine' bakmak, ilmin temel ilkesidir. Eskilerden gelen tutumlarin başında, kelime düşmanlığı da vardı. Mesela felsefeye düşmanlık, bu kelimenin Yunanca olmasındandır. Eğer Yunan milleti ilk dönemlerde müslüman olsayd, bu kelimeye bu kadar düşmanlık olmazd. Siz felsefeyi Arapça'ya "hikmet"'diye tercüme ederek kullanırsanız, herkes aynı anlamı 'hikmet' kelimesinin içinde kolaylıkla kabul eder. ama 'hikmet'e felsefe derseniz, isyan eder, hayır felsefe değil, hikmet der durur. Günümüzde demokrasi kelimesi, ve reform kelimesi de İslâmcı kesimde, aynı cezaya çarptırılmaktadır. Oysa demokrasi şûra adı altında, reform, tecdîd adı altında, laiklik, din işi, devlet işi adı altında tartışılmış olsa görülür ki, karşıt olanlar daha sempati ile her biri kendi meselesi ile uğraşıyor durumda olarak anlayışla tartı̧̧ırlar.

Senelerce önce Hz. Peygamber'in 'Íkindi namazı Benû Kurayza'da kılınacak' sözünün hikayesini ve anlamını kitabımda yazmıştım. Sandım ki, biraz İslâm tarihini ve kültürünü bilen bunu anlar. Sonra kitaplarla uğraşan benim yaşımda bir adam bana, bunu niçin yazdığımı sordu. Ben de sebebini anlattım. Anladım ki, bir tarihî olayı anlatırken ondan anlaşılması gereken dersi ayrıca vurgulayarak açıklamak gerekiyor. Kuşkusuz düşünen kimse, anlatılan bir olaydan neler anlamak gerektiğini anlar ve anlayana da rastladım. Mesela üç sene önce Barselona'da Dünya Eğitim Sempozyumunda karşılaştığım bir Türk Profesörüne sohbet esnasında, müslümanların nasıl İslam'dan ve Kur'ân'dan saptıklarını anlatırken dedim ki: Dokuzuncu Mîlâdî (Hicrî üçüncü) asırda, mezhepler teşekkül ettikten sonra, mezhebe bağlı alimler, hep mezhep kurucusu imamları adına konuşmaya başladılar. İmamımız veya falan imam şöyle söyledi, demeyi gelenek ve daha çok onu önemli bir kural haline getirdiler. Bunlara 'mukallit' denir. Bu adı da kendilerine, kendileri taktılar. Bunlar kendi sahalarında konuşacak ilmî şahsiyet ve fikir sahibi değildi. Başkasının adına konuşmanın, İslam'da en büyük sapma ve yanlış olduğunu anlattım.

Bu tarihî bir olaydır. Biraz sustuktan sonra ben profesöre buna günümüzdeki ilâhiyatçıların dışındaki kişilerden, özellikle sağcı aslen ideolojistlerden ve siyasetçilerden örnekler verince, bana dedi $\mathrm{ki}$, siz anlatınca ben zaten günümüzdekileri anladım. Ne var ki, böyle anlayışlı zatı ilahiyatçılarda bile bulmak zor oluyor. Onlara göre tarihi olaylar, şartlarına göre olmuş, bitmiş ve kutsallık kazanmışlardır. Onun için o olaylara bakarak başka yeni bir şey anlamak, bir yenilik olacağı için asla öyle bir yeniliğe ve bid'ate gidilemez, davası güdülmektedir. Din hep tarih olarak anlatılıyor. Hayatta nasıl olması gerektiği anlatılmıyor. Kanunlara en çok uymayan, kanunu yapanlar olduğu gibi, dine de en çok uymayanlar din adamlarıdır ve 
din okutucularıdır. Ayrıca yanlış anlattıkları dinin yanlışlarına daha çok uyuyorlar. Böyle olan bir müslüman din adamına kıymet verilen bir toplumda bir iyilik ve hayır bulunur mu?

\section{Gerekçe - Söylemin Nedeni}

Yukarıda değindiğim Benû Kurayza olayını burada açıklayarak İslam'da din anlayışına temel teşkil eden iki anlayış farkını ve zihniyetini temellendirmek gerekiyor.

Hendek savaşında müslümanlarla olan anlaşmayı bozup müslümanları arkadan vurmak isteyen Benû Kurayza kabilesiyle savaşmak için $\mathrm{Hz}$. Peygamber'in söylediği şu sözün anlaşılmasında sahabe iki ayrı gruba ayrılmıştır: "İkindi namazı Benû Kurayza'da kılınacak.'

Müslümanlar Benû Kurayza yolunda iken akşam olmak üzeredir. İkindi vaktinde Benû Kurayza'ya varamayacaklarını anladılar. Ne yapacaklarını aralarında tartıştılar. Kimisi dedi ki, Hz. Peygamber Benû Kurayza'da kılınacak dediğine göre vakit ne olursa olsun, ikindi namazı orada kılınacak, demektir; çünkü Hz. peygamber'in sözü de 'şerî'at'tır. Kimi sahâbe de dedi $\mathrm{ki}, \mathrm{Hz}$. Peygamber'in bu sözü söylemesinin amacına bakalım. Hz. Peygamber'in amacı. o kadar süratli gidilecek ki, güneş batmadan oraya varılacak ve ikindi namazı, güneş batmadan orada kılınacaktır; ikindi namazı hem Kur'ân'ın emri, hem de vakte bağlı önemli ibâdetlerden biridir. Biz $\mathrm{Hz}$. Peygamber'in bu sözünün amacını, söylemesinin sebebini böyle anlıyoruz. Bu sebep namazın vaktini değiştirmeyi gerektirmeyeceği için, biz ikindi namazını Benû Kurayza'ya varmadan kılarız, dediler ve yolda namazı kıldılar. Ötekiler ise ikindi namazını güneş battıktan sonra, ulaştıkları Benû Kurayza'da kıldılar. Bu iki grubun fikri ve uygulamalarına $\mathrm{Hz}$. Peygamber bir ses çıkarmadı. Herkesin anlayışı, kendi anlayı̧ seviyesini gösteriyordu. Bu iki grubun topluma hakim olmalarının etkisini kısaca izleyelim.

İslâm bilginleri bu olayı iyi değerlendirerek insanları iki büyük karşıt gruba ayırdılar:

a) Sözlük anlamına takılıp bağlı kalanlarına, ki bunlar sözlük anlamına göre hareket edip ikindiyi Benû Kurayza'da kılanlardır. Bunlara Lafızcılar(lafziyyûn) adını verdiler. Sonraları bunu metot, yöntem olarak benimseyenlere 'Zâhirîler' dendi ve böylece Zahin̂ mezhebi doğdu. Ancak başlangıçta zahirî, lafızcı olmayan mezheplerin imamlarına uymayı gelenek haline getirip ilk imamların sözlerine takılıp bağlı kalmayı yeğleyenler ve kendilerine 'mukallit' diyenler de Zâhin̂ler gibi düşünüp davranarak sadece imamlarının sözlerini anlamakla yetinenlere 'Nasscılar' (nassiyyûn), nass'a, söze bağlı kalanlar denmiştir. Bunlar mezhepçiler, mukallitler olup her zaman yeni bir fikir üretmeğe ve yeni bir içtihât yapmaya karşı çıkarlar; bunlar günümüzde de İslâm millet ve toplumlarına siyasilerin çıkarlarının etkisinde hakimiyetlerini sürdürmekte, müslümanları düşünceden, bilgiden ve medeniyetten geri bırakmaktadırlar. Ve bunu da cahil ve düşüncesiz 
bırakılan halka en iyi müslümanlık olarak aşılamakta ve öğütlemektedirler. İslâm dünyasının bütün sıkıntısı, başbelâları bunlardır. Mezhep imamlarını ve mezhep içtihatlarını nass(Kur'ân metni) yerinde görerek onlara nass işlemi yapanlar, onları lafızcı gibi anlar ve onların yanlışlarına yanlış bile diyemezler; çünkü yanlışı doğrudan ayırdedemezler.

İşte . Benû Kurayza olayında lafızcıların İslâm din ve düşünce tarihindeki serencamının, varlığının sonucu budur.

b) Hz. Peygamber'in sözünü söylemesinin amacına göre yorumlayarak ikindi namazını Benû Kurayza'ya varmadan yolda kılanlara akılcılar(akliyyûn) adını vermişlerdi. Çünkü bunlar iki şeyi karşılaştırdılar: Biri, ikindi namazını vaktinde kılmanın farz, gerekli olması ile $\mathrm{Hz}$. Peygamber'in sözünün sonucunu bu farzı zamanında îfâ etmenin imkansızlığ 1 ile karşılaştırdılar. Hz. peygamber'in sözü açıkça ikindi namazının vaktini güneş battıktan sonraya alınmasına âit bir ifade yoktu. Bu şu demekti: İkindi namazını güneş batmadan, Benû Kurayza'da kılmağa çalışın. Benû Kurayza'da kılınması gene güneş batmadan olacaktır. Namaz güneş batmadan olacaksa, o zaman Benû Kurayza'ya varmadan kılınmalıydı. İşte Hz. peygamber'in sözünden amacının çok hızlı ve süratli, gitmeyi anladılar. Yoksa ikindi namazının vakti o an için kaldırılmadı. Süratli gittiler, ancak yetişemeyeceklerini anlayınca namazı yolda kıldılar. Her iki taraf da Hz. peygamber'in sözüne göre hareket etti. Birinci grup sözün, sözlük anlamına, ne dediğine baktı, ona göre hareket etti; anlayışları o kadardı; ikinci grup ise sözden ne demek istendiğine, sözün amacının ne olduğuna baktı. Ve anladığına göre hareket etti. biz bu hususta şu deyimi ortaya atıyoruz: Ne dedi? Ne demek istedi?

$\mathrm{Ne}$ dedi'yi herkes anlar, bunu anlamakta cahil, alim, çocuk, büyük arasında fark yoktur; çünkü sözlük anlamında hiçbiri bir emek vermiyor ve aklını çalıştırmıyor, çalıştırmasına ihtiyaç bulunmuyor. Bunun için ne dedi'yi anlamak, emeksiz bir anlayış olduğundan, buna 'içtihât' denmez. Ne demek istedi'yi anlamak için kafayı çalıştırmaya ve bir zihnî emek vermeğe ihtiyaç olduğundan dolayı, buna 'içtihât' denilir. Öyleyse, ne demek istediğini anlamak içtihattır. Ve bu içtihatla olur. içtihât artı bir gayret ve güç sarfetmedir. Bu ne dedi ve ne demek istedi? Her türlü söze, yazıya, metne, Kur'ân'a, hadîse, herhangi bir adamın, filozofun sözüne uygulanabilecek bir kuraldır.

Günümüzde ilâhiyatçllar (gene hepsine din bilginleri diyelim) böylece iki gruba ayriliyorlar: 'Ne dedi'de kalanlar, onda direnenler; tutucular, yenilik karşıtları; 'ne dedi'den hereket edip 'ne demek istedi' ğine giden, yenilikçiler, fikir üretenler. Mücadele bu iki grup arasında olup bin yüz yıldan beri 'ne dedi'ciler günümüzde de topluma, halka, devletlere hâkimdirler. İslâm medeniyetinin yeniden doğmasını engelleyen bunlardır. Müslümanların başına dert getiren bunlardır.

Illk asırda, büyük yaşlı sahabeler döneminde, İslâm toplumu genişlemiş, nüfuzu çoğalmış, değişik milletler ve dinler, devletin idaresi altına girmişti. 
Bundan dolayı, devletin idaresinde birçok yenilikler yapmak, çok değişik halkın, değişik ihtiyaçlarına cevap vermek, çözüm getirmek gerekmekteydi. Bütün bu ihtiyaçların çözümü içtihâtlarla, akıl yürütmekle yapıldı. Aklını kullanmayıp yalnızca çocuklar kadar Kur'ân'ın ve hadislerin sözlük anlamlarında takılıp kalanlar, bu içtihâtlara, yeniliklere-çünkü içtihât, yeni bir fikir ortaya koymaktır-bid'at diyerek karşı çıkmağa başladılar. Ancak topluma hakim olan zihniyet akılcılık ve içtihât olduğu için yenilik (bid'at) düşmanları seslerini fazla çıkaramadılar. Ne var ki yenilik, bid'at düşmanları düşmanlıklarını sürdürmeğe devam ettiler. İslâm'ın ilk üç asırlık dönemde devlet yeni kurulduğu ve yeni yapılandığı, devletin de yerleşmiş bir geleneği olmadığı için, akılcılar daha rahat ilim yaptılar ve fikir ürettiler, içtihât ettiler, felsefe yaptılar. İlk üç asrın sonunda mezhepler kurumlaştı. Devlet sistemi gelenekselleştiği için, taklit başlad, artık böylece söylemleri, sözleri, yazılanları, Kur'ân ve hadisi bile, anlamak sözlükçülerin, lafızcıların hâkimiyeti altına girdi.

Bugün on bir asır sonra yenilik düşmanlığı, daha şiddetli bir biçimde sürüyor. Hele son üç asırdan beri, müslüman milletlerin başına bunca felâket, belâ gelmesinden de hâlâ akılları başlarına gelmemiş ve bunların oluş nedenlerini de yenilik, bid'at ve reform düşmanlığı olduğunun bilincine bile varamamalarının nedeni, akıllarını kullanmamalarıdır.

İlk asırlardaki yenileme, yani bid'at taraftarı olanlar, akıllarını kullandıkları için, yenilemenin, bid'atin felsefesini yapmışlar ve yeni bir şey ortaya koymak iki sonuç verir ,demişlerdir: Bu yeni şey ya iyi, doğru, güzel olur veya bu yeni şey yanlış, kötü ve zararlı olur. Bunlardan birincisine 'bid'at-i hasene' ikincisine ise 'bid'at-i seyyie'(güzel bid'at ve kötü bid'at) adını verdiler ve bu ayrımı getirdiler. Bu her zaman günümüzde de uygulanacak bir ilkedir. Kur'ân'ın felsefesini ifade eder. Faydah, güzel, iyi her şey, her zaman meşru ve doğrudur. Zararl, çirkin, kötü bir şey hiçbir zaman meşru ve doğru değildir. Aslında bu, kavramın temel felsefesine dayanır. Böylece yenilik düşmanları nefeslerini zamanında biraz kısmış ve kesmişlerdi. Son asırlarda, İslâm milletleri, içeriden hiçbir yenilik yapmadılar ve yeniliklerin her türlüsü dışarıdan, düşman milletlerden geldiği için, hangi yenilik olursa olsun, doğru-yanlış olduğuna bakılmadan, karşı çıkmayı, iyi dindarlık sayarak düşmanlığı gelenek ve töre haline getirmişlerdir.

Burada dikkat çekmek istediģim yöntem şudur: Toplumu tıkayan gelenekçiler, taklitçiler, yeniliğin karşısına akılları ile değil, gelenekleri ile çıtıkları için, yeniliklerin de kötülerinin, yani bid'at-i seyyi'elerin hücumuna uğradılar, sersemleştiler, şaşkın şaşkın gene de yenilenmeye düşmanlığı dindarlık olarak her tarafta yaymaktadırlar. Bunların yeni medeniyetin tekniğinden yararlanma zorunda kalmaları, gene bilinçsizce olduğu için, yeniliğe izin vermeye yanaşmıyorlar, dindarlıklarını dinin aleyhine reklam olacak biçimde yapmaya çalışıyorlar. Biraz akıllı görünmek isteyenler, yeniliğin iyisinin karşısında olmadıklarını söyleyerek, yine de 
yenilik düşmanlığının avukatlığını yapanlar bile sözlerinin sonunu eski geleneksel, taklitçi mantığa göre uyarladıkları için yeninin iyisini ve kötüsünü ayırdedemiyorlar. Geçmişe özlemlerini sürdürüyorlar. Bunda basit halkın geleneğini din edinen grupların maddî ve manevî baskısı inkâr edilemez.

\section{Hz. Ömer'in Reformları/ççtihatları}

$\mathrm{Hz}$. Ömer'in yaptı̆̆ı yenilikler bir Fransız veya İngiliz ya da Alman müslümanı tarafından kaleme alınmış olsa, onlara $\mathrm{Hz}$. Ömer'in reformları, der. Arapça'da 'tecdîd' Türkçe'de 'yenilik' diyoruz. O hâlde reform kelimesine düşman olmanın anlamı yoktur. Ne olursa olsun, adam düşünmek istemiyorsa, hep alışılagelmiş sözleri, sözcükleri kullanmak istiyorsa, onun kafası buz tutmuş, hayatiyetini, canlılığını kaybetmiş demektir. Dünyada olan düşünsel, bilimsel değişimlerin başlangıç noktası, sözcük ve söylem değişikliğidir. Yeni bir söz ve sözcük insanın dikkatini çeker, zihnini uyandırır. Geleneksel taklitçiler bu tür sözleri işittiğinde hemen 'zaten ben bunları biliyorum' deyip konuya girerek, söylenecekleri kanıksar, önemsemez. Bunun içindir ki, edipler bile aynı anlamda olan bir manayı daha vurgulu anlatmak için başka kelimeleri kullanırlar $\mathrm{ki}$, dinleyen veya okuyan zihnî bir zevke ve çeşitliligge kulak versin. Bir dilde ne kadar kelime varsa, o dilde en ince manaları anlatma imkânı o kadar bulunmaktadır. Bütün canlı, ilim ve felsefe dilleri hep bir birinden kelime alırlar, eğer yabancı kelime, kendi dil kurallarına uyumlu olmuyorsa, zamanla o manayı ifâde eden kelimeyi kendi dillerinde türetir veya icat ederler. Diller, ilimler, felsefeler böyle gelişir ve düşünme yeteneği böyle yükselir.

Bunun için, her defasında reform kelimesini kullanmayı yeğliyorum. Kuşkusuz İslâm toplumlarında herhangi bir alanda, idarede, siyasette, ilimde ve ilmin bütün dallarında bir ilerleme, gelişme, kalkınma ancak dinde reformdan geçer. Çünkü her türlü ideoloji ve bilgiden insana her an ve her yerde etki gücüne sahip, onu yönlendirecek, onu tembellikten vurdumduymazlıktan, uyuşukluktan, hirsızlıktan, soygunculuktan, zulümden, kıyımcılıktan, kurtaracak din bilinci, din kültürü, din inancıdır. Bilim durağandır; geçmişi betimler, tasvir eder, anlatır ve orada kalır; o bilimi eylem hâline getirecek olan inançtır. İnancın en güçlüsü dinde ve Allah'a inançla vücut bulur. İdeolojilerdeki inancın eylem yaptırması, sürekli ve kalıcı olmaz. Dindeki inancın bir evrensel vazifesi, insanın ruhunun derinliklerinde merkezi vardır. Bunun için insana bir iş yaptırmak istiyorsanız, onu dininin esaslarına göre ona anlatın. İnsanın en güzel niteliği, güvenilir, yani gerçekten dindar olmasıdır. Insanı iyi dindar yapmak için, İslâm dînine (iyi insan projesine) göre okutmalı ve eğitmelidir. Yoksa dinsiz yapmakla bireyi, toplumu felâkete sürüklemek olur. İnsan dinle iyi insan olmuyorsa, hiçbir şeyle iyi insan olmaz. 
Osmanlı imparatorluğunda birçok yenilikler, reformlar yapılmıştı. Ama o zaman onlara ne yenilik ne de islâhât diyebilmişlerdi. Çünkü toplum ve medrese yenilik ve islâhât kelimelerine ve onların işleme konulmasına karşı idi. Bundan dolayı ilk resmî ıslâhâta 'Tanzîmat' adını vermek suretiyle yeniliklere resmî bir kelime bulunmuş oldu. Ancak Tanzîmat'tan on altı yıl sonra ıslâhat kelimesi kullanılabilmiştir. Çünkü medrese de medrese sistemine bağlı, fakat medrese dışında yeni bir programla kadı yetişme okulu açmıştı (1854). Bundan sonra artık medrese de devletten kendisini ıslâh etmesini istemeğe başladı. Medresenin ıslâhı ancak 1914 yılında gerçekleşti. Birinci Dünya savaşı, İstiklâl savaşı nedeniyle medresenin ıslâhı işe yaramadı; çünkü pek geç kalmıştı.

Önemli bir zihniyeti açıklamak istiyorum: Bu zihniyetin tespitinin birincisi, okumalarıma, ikincisi gördüklerime ve duyduklarıma dayanıyor. 1774 'de eğitimde başlayan yenilik ve ayrılık 1880 'lere kadar tam bir sistem hâlinde gelişti. 1774 'den önce her türlü eğitim medresede yapılırken bundan sonra başlayan ayrı eğitim yüz sene zarfında medresenin yerine geçebilecek hem de çağın bilimlerini de okutan bir sistem haline gelince, medrese hocası ve öğrencisi, artık medreseye ihtiyaç kalmayacağını ve dolayısıyla kapatılacağını kavramış, hemen hem hocası, hem eli kalem tutan öğrencisi, medresenin ıslâhı için, feryat etmeğe, bunu devlete anlatıp kabul ettirmek için medrese ıslâhât programına dâir kitaplar, makâleler yayımlamağa başladı.

Şeyhulislâm olan Hayri Ürgüplü 1914'de medrese ıslâhâtını modern bir şekilde gerçekleştirdi. O zamanki medrese hocası ve öğrencisi, medresenin ıslâhının gerektiğine inanmıştı. Günümüzde ise, eski medresenin özlemini çekip onu diriltmeyi düşünen, bunun propagandasını yapanlar var. İşte iki zihniyet: medreseyi son yaşayanlar yenilik ve islâhât taraftarı, medreseyi hayâl edenler, ıslâhat ve yenilik karşıtı. Bu da din anlayışında yüz sene öncesinden geri olduğumuzun tarihi bir delilidir. Yeniliğe karşı çıkmanın ilk ve açık belirtisi, eskiyi olduğu gibi koruyup yaşatmağa çalışma ve onu en iyi dindarlık olarak görmedir.

Bizim dinde reform yapma dileğimiz, devleti de ancak bu yolla reform yapmaya özendirebiliriz düşüncemizden kaynaklanmaktadır. Çünkü devlet, dinde reform yapmayı istemediği için, dinde reform yapacak din bilginlerini yetiştirmeye hiç istekli değildir. Dinde reform olduğu ve gerçekleştiği zaman, devletin 1774 'den beri beceremediģi çağdaşlaşmayı, çok kısa bir sürede gerçekleştirmek imkânı elde edilecektir. Bunu Nâmık Kemâl de söylemiştir.

Bizim tarihi tespitimiz sonucunda ortaya koyduğumuz ilke şudur: Devlet medeniyet kuramaz. Medeniyeti millet kurar. Dinde reform milleti çağdaşlaştıracaktır ve medeniyeti millet kuracaktır. Benim iddiam budur. Bunun kanıtı ise bütün insanlık ve İslâm tarihidir.

Bu iki anlam dinde kullanılmıştır. Şimdi de kullanılma gereği vardır. Örnekleri İslam'ın uygulanışından aldım. İslam'da en büyük İnkılapçı 
(müceddid), yenilikçi, $H z$. Ömer'i görmek lazımdır. Böyle bir zatın hiç yanlış yapmadığını iddia etmek saçma olduğu için onu yanılmaz olan Allahlık katına çıkarmak olur. Hz. Ömer'in yanlışları da olmuştu. Ancak yanlışın yanlış olduğunu bilmeden yapmıştır. Bilerek yapılan yanlışlık hıyanettir. Yukarıda vurguladığım noktayı örneklemek isterim:

Yeni müslüman olanlara -zengin de olsalar-zekattan pay verilirdi ki, başkalarının kışkırtmalarına kapılıp İslam'a düşman olmayıp müslümanlıklarına devam etmeye özendirilirler. Buna dair âyet $\mathrm{Hz}$. Peygamber zamanında lafzı (sözlük) anlamına göre uygulanmıştı. $H z$. Ebubekr devlet başkanı olunca, $\mathrm{Hz}$. Ömer'i mâlî işlere memur etmişti. $\mathrm{Hz}$. Peygamber zamanında zekat alan zenginler, Ebubekr'e gelip haklarını istediler; Ebubekr onları Ömer'e gönderdi. Ömer ise onlara zekattan paylarını vermemiştir: "Artık sizi boşuna beslemeye gerek yok. Biz şimdi artık güçlü durumdayız' diye cevap verince, onlar tekrar Ebûbekr'e giderler. Ancak Ebûbekr: 'Ömer ne dediyse öyledir' der. Böylece Ömer, Hz. Peygamber'in sözkonusu âyeti uygulamasını değiştirir. Ebubekr ve diğer ileri gelen müslümanlar (bunların içlerinde $\mathrm{Hz}$. Ali de vardır), Ömer'in bu uygulamasını onaylarlar. Bu olayı eserlerimde daha çok açıkladım. Bunu herkes biliyor, ancak kimse bundan bir anlam çıkaramıyor. Çıkarmaya da akıl yormuyor ya da tenezzül etmiyor.

$\mathrm{Hz}$. Ömer öyle yaptığı zaman, Hz. Peygamber' in ölümünden henüz bir yıl geçmemişti. Şimdi bin dört yüz yıl geçmiş olduğu halde, bin dört yüz yil önceki bir müçtehit sözünü hâlâ o zamanki uygulamasına tıpa tıp uygulamak ve onun en iyi dindarlık olduğuna inanmak, düşünmeye tenezzül etmemekle nitelendirilmesi gerekmez mi? Gene Hz. Ömer'den bu sefer yanlı̧ olan bir içtihadını da zikretmek iyi olur. Bir cümlede üç kelimesini kullanarak karısını bir kalemde, bir daha evlenemeyecek şekilde tek bir cümle ile boşamayı uygulaması da yanlıştı. Nitekim bazı mezhepler bu uygulamayı Kur'ân gibi nass kabul edip, uygulamaya bin dört yüz yıl sonra devam etmeleri de tam anlamı ile saçma ve hatalıdır. Bunu Ibn Teymiye bile reddetmişti. Ancak âlimlere, topluma devlet düşünme yasağı koymuştu. Bu yüzden düşüncesizlik yaygın ve hâkimdi.

Kitaplarımda, makalelerimde bu konuda gereği kadar açıklamalar ve örnekler olduğu için, Kur'ân'a samimiyetle inananlara Kur'an'ın çağrısını duyurmak istiyorum. Kur'an'ın çağrısı şudur: Düşün!

Düşünmek, söylenenin, nakledilenin, duyulanın, duyurulanın doğru olup olmadığını araştırmak ve hepsinin sonunda bir kimsenin etkisi ve telkini altında kalmadan, daha önceki fikirlerine uyup uymadığına bakmadan, sadece, araştırmalarla elde ettiği bilgilerle başbaşa kalarak hükmünü ve kararını vermektir. İslâm dünyası bin yüz yıldır, böyle bir düşünceye yönelmediği ve bunu beceremediği için bugün bin dört yüz yıl sonra, dünya milletlerinin en gerisinde kalanlarla beraber olma durumuna düşmüştür. Bunlar, Kur'ân'ın düşünmeyenlere verdiği niteliklerden bir ikisidir. O halde bunlardan kurtulup insan olmak ve Allah'ın sorumlu kulu 
olmak için Kur'ân'ın çağrısına uy!. Düşün!..Düşünmek, başkasının söylediğini tekrarlamak olmayıp ona ters, aykırı bir fikir, söylem ve deyim ortaya koyabilmektir. Söylenenin yanlış veya doğruluğunu tartmak, onun girdisini, çıktısını anlamaya çalışmaktır.

$\mathrm{Bu}$ örnekleri tarihî olay olarak verirken çok kimse sanıyor ki, bir tarihi olay anlatılıyor, hepsi o kadar. Doğrusu durum, sanıldığı gibi değildir. Nitekim Kur'ân da gerçekleri hep olaylarda uygulayarak anlatıyor. Anlamak isteyen, onun neyi anlatmak istediğini anlıyor. Anlamak istemeyene göre tarihte herhangi bir olay olmuş, geçip gitmiş, iş bitmiştir. Onun içindir ki anlatılandan bir fayda, bilgi ve anlayış elde edilemiyor.

Biz de tarihteki olayları anlatıyoruz. Onlardan ders alınsın, aynı ve benzeri olayları ona göre zamanımıza en uygun olacak şekilde düzeltelim. $\mathrm{Hz}$. Ömer'in kocanın karısını boşaması hususunda verdiği hüküm Kur'ân'a da tersti. Kendisi âyeti toplumun, insanın yararına yorumladı, ancak yanlış yorumlamıştı. O yanlış yorumlamaya dayanan hüküm, zamanında ne derece yararlı olduğu bilgisine sahip değiliz. Ancak bin dört yüz yıl sonra günümüzde Anadolu'da dine, şeriata, ahlâka, aykırı, zıt eylemlere sebep oluyor ki, rezaletler başa bela, insanların haysiyetini aşağılamaktan başka bir işe yaramıyor. İşte bu yüzden $\mathrm{Hz}$. Ömer'in boşanma ile ilgili içtihâdı hemen kaldırılmalıdır. Bu uygulama, dine sokulan büyük yanlışlardan birisidir.

Bütün yazılarımızda açıklamağa çalıştığımız gerçek din hükümlerinin dayană̆ı Kur'ân ve sağlam hadislerle, onları doğru anlayan 'muhakkik' âlimlerin sözleridir. Bir içtihadın, verilen bir hükmün doğruluğunu anlamak, onun Kur'ân'a uyup uymadığı yanında olaya en uygun-hem ahlâk, hem akıl, hem bilim yönünden- çözüm getiriyorsa, o hüküm doğru bir hüküm ve onu anlama doğru bir anlama olur.

$\mathrm{Hz}$. Ömer'den örnek veriyorum ki sorunu temelinden, daha ilk baştan kimsenin itiraz etme imkanı olmayan bir açıklıkta ortaya koyalım. Çünkü $\mathrm{Hz}$. Ömer hem halife, hem ileri gelen bir sahabe, hem büyük bir müçtehit, Müslümanların imparatorluğunun temelini atmış âdil bir idâreci ve büyük bir siyaset adamıdır. Kur'ân'da hırsızın elinin kesilmesi hükmüne şart getirmiş ve hırsızın elini kesmemiştir. Birçok kimse, Kur'ân'ın bazı cezâî hükümleri uygulanacak diye endişe ediyorlar. Ben de onlara diyorum ki, âdil olmakta, şeriatı, kânunu uygulamakta ün yapmış $\mathrm{Hz}$. Ömer'in adâleti el kesmek değil, el kesmemekti. Biz Hz. Ömer'i Kur'ân ve akıl (bilim-olay) terazisine koyuyoruz. Doğru ise doğrudur, yanlış ise yanlış. İşte devletimiz, toplumumuz, bireyimiz, hükümetlerimiz bu ölçüye uyduklarında hem mutlu bir millet, hem medenî bir millet oluruz. Bir milletin içinde suç işleyenleri cezalandırmak için dünya milletleri tarafından çok değişik ölçüler alınır ve cezalar verilir. Kur'ân da mutlu, uyumlu, ahlâklı; hakka, hukuka, dayalı bir insan toplumu istemektedir. Suçlara verdiği cezalar, o suçun bir daha işlenmemesini sağlamaktır. Yoksa sırf suçluyu acıtmak olmayıp suçu önlemektir. Kur'an en son başvurulacak cezâyı söylüyor. O cezaya gerek kalmadan, o cezaya gelinceye kadar birçok yollarla o suç önlenebiliyorsa, 
onlarla önlenir ve en son ağır cezaya gerek kalmaz. Kur'ân'ın felsefesi, o kadar ağır bir cezâ verilmesi gerekiyorsa, onu icra etmeye izin veriyor. Verdiği emir şarta, duruma göre uygulanır, uyarlanır. Müslümanlar da tarihte böyle uygulamışlardı. Aslında Kur'an'ın cezalarını ağır görenler, Kur'ân'ın hiç tasvip etmediği insanlık dışı işkenceleri uygulamakta ve uygulanmasına en azından göz yummakta, izin vermekte ve bundan da zevk almakta, sevinmektedirler. Kur'ân bir kimseye kısas yapılmasına hükmeder, ama ona işkence ve hakâret edilmesine izin vermez.

\section{6. Şirk Tehlikesi}

Hz. Ömer'in Kur'ân'ın amacına ve felsefesine uygun işlerinden birisi de Hz. Peygamber' in Kureyş ile, Hudeybiye andlaşmasını altında yaptığı ağacı (şecerat'ür-Rıdvân) kesip kökünden yok etmesidir. Hz. Peygamber'in ölümünden sonra bazı müslümanlar o ağacın altında toplanıp duâ etmek ve bereketlenmek teşebbüsünde bulundukları için $\mathrm{Hz}$. Ömer bu ağacı kökünden söküp atmıştı. Sonraları ve hele günümüzde namaz kılan müslümanlar arasında yayılmaya başlayan insanlara, efendilere, türbelere boyun bükerek etek öpmelere varan saygı ve hürmet tapıcılık derecesine vardırılmaktadır. Allah'ın sözüne değil, efendinin sözüne daha çok önem verilmekte olması, Kur'ân'ın şiddetle reddettiği şirkin devamından başka bir şey değildir.

Bu gün İslâm'da en tehlikeli, en aşağılayıcı, sapkınlık ve hurâfe, İslâm'a sokulan bu şirktir. Allah'ı bırakıp başkasından yardım ve mağfiret dilemek, Hıristiyanların $\mathrm{Hz}$. İsa'dan yardım dilemeleri ve ona tapınmalarını beğenmeyen namaz kılan müslümanlar-namaz kılmayan müslümanlar içinden de varsa da, namaz kılanlar daha sağlam, daha gerçek, Kur'ân'a daha bağlı oldukları sanıldığı için-aslında öyle olmaları gerekirken efendilerine, şeyhlerine taparcasına yaptıkları hareketlerin, saygınlıklarını ve onların sözlerine yüzde yüz gerçekmiş gibi yanılmazlık derecesinde inançlarının onlara taptıkları ve onları ilâh kabul ettiklerinin farkında olmamaları ne kadar acıklıdır. Bunları yapmak yanlış ise, öyle yapmıyoruz diyemezler. Çünkü herkes onları görüyor. Yanlışlığını kabul etmemek affa uğrama sebebi olamaz. Doğrudur diye yaptığı için tövbeye de gerek görmez. Şirkin içinde şirk olmaz $\mathrm{mı}$ ?

Şu hususu gözden kaçırmamalı ve akıldan çıkarmamalıdır: Namaz kılan, Allah diyen putperest, müşrik olabilir. Zira namaz kılmak, Allah demek putperest olmaya engel olmayabilir. Arap putperestleri de Allah diyorlardı. -Meselâ Abdullah adı, özel ad olarak İslâm'dan önce Araplar arasında yaygın olarak kullanılıyordu- Ama, yine de putperest idiler; çünkü gidip başka varlıkların yanında ibâdet ediyorlar ve onların aracılığıyla Allah'a yaklaşacaklarına inanıyor, bu inançlarına göre saygıyı artırıyor ve huzur duyuyorlardı. Şimdi burada benim önerim şudur: Müritler kendi vicdanlarına danışsınlar, kendileri hüküm versinler. Ne şeyhlerine, ne de din 
âlimlerine sorsunlar. Namaz kılmanın putperestliğe engel olmadığına en açık kanıt şu olay zikredilmektedir:

Hz. Peygamber Mekke'yi fethettikten sonra, Tâif'i de fethetmek istedi, ama olmadi. Medine'ye döndü. Ancak Mekke müslüman olduktan sonra, diğer kabilelerin müslüman olmaktan başka çare olmadığını görmeleri üzerine, Medîne'ye akın edip müslüman olmaya başladılar. Böylece Tâif'in etraf 1 müslümanlarla çevrilmiş oldu. Tâif de bir heyet teşkil ederek Medîne'ye gönderdi. Hz. Peygamber'le birkaç gün anlaşma için müzakere ettiler ve tartıştılar. Her şeyi kabul ettiler. Allah'a, Kur'ân'a, ve Hz. Muhammed'e inanmayı, namazı, orucu, zekatı, kabul ettiler. Yalnız bir şey istediler: Atalarından beri tapageldikleri Lât, tanrısına saygıları, sevgileri çok köklü olduğu için, onun yıkılmasını üç sene geciktirmesini istediler. $\mathrm{Hz}$. Muhammed kabul etmedi. İki seneye, bir seneye, altı aya, bir aya kadar inip yıkılmamasına izin istemekte ısâr ettiler. Hz. Peygamber kabul etmedi. Artık putun yıkılmasını da kabul ettiler ve hiç olmazsa bize yıktırma dediler. Hz. Peygamber Kureyş'ten olan Tâif' in dostlarını gönderip o putu yıktırdı. İşte bunlar namaz kılmayı kabul ettikleri halde, puta karşı besledikleri sevgi ve saygıdan dolayı, putperestlikten kurtulamamışlardı. Putperest Arap bunları kabul etti müslüman oldu, ama şimdiki müslümanlar putperest Araplar kadar kafalarını çalıştıramıyorlarsa, gösterdiği saygının tapmak olduğunu anlamıyorsa, varacakları yerin ateş olduğunu kavramayan müride de şeyhe de Allah akıl ve insaf versin demekten başka, samimi müslümanın elinden ne gelir? Allah tövbe nasip etsin!

Kur'ân'ın yetiştirdiği insanın derdi Kur'ân'ın evrensel ilkelerini yürürlüğe koymaktır. Kur'ân'ın yetiştirdiği insan evrensel düşünmeye, evrensel insan haklarına göre herkesin-bireyin, toplumun, milletin, hükümetin, devletin-çalışması, davranması, işlem yapması, çalıştırılması; gerektiğine içten inanması, ömür törpüleyen mensubiyet özentisini, çıkarcıll̆̆ı gözardı ederek bireyin, toplumun, milletin üzülmesi ile üzülen, sevinmesi ile sevinen insandır. Bunu tarikatlerde, mezheplerde, gruplarda, ideolojik kurumlarda görememek, Kur'ân müminini üzmektedir.

Birinci Din Şurasında, fıkıh yazanlar ölmüştür; fıkıh da eskimiştir; yeni bir fıkıh yazmaya gerek vardır, dediğimde, meslekten bir profesör, fıkhın da doğruları vardır, cevabını vermişti. Ben ona şöyle karşılık verdim: Fıkhın doğrularını, fıkhın içinden çıkaramazsınız; fıkhın doğrularını ortaya koyabilmek için, fıkhın dışında bir ölçüt bulmanız gerekir. Bu ölçüt Kur'ân'dır. Kur'ân'ı anlamak için de akıl birinci temel esastır, dedim. İşte bu sözüm bir önerme, bir ilkedir. Bunu uygulamak için, kuşkusuz bilgiye gereksinim bulunmaktadır.

İkinci önermem bunun uygulanmasıdır.

Geçmişteki hükümleri, olayları üçe ayırıyorum:

a) Zamanında doğru olduğu tespit edilip her zaman doğru olan evrensel ilkeler, hükümler. Bunlar her zaman, her yerde ve herkese uygulanabilen mutlak hükümlerdir. Bunlar öz ve doğruluk bakımından 
değişmezlik ifade ederler; ancak şartlara göre amaçlarına uygun olarak değişik uygulamalara yer verecek kadar geniş kapsamlıdırlar.

b) Zamanındaki şartlara göre uygun olan göreli, izâfî doğruluk ve gerçeklik ifâde eden hükümler. Şartlar değişince bunlar değişir ve tamamen gözardı edilirler ve tarihe geçerler, tarih olurlar.

c) Zamanında yanlı̧̧ olanlar ve her zaman yanlış olabilenler. Geçmişteki yanlışları, doğrulamak, doğruluklarını ispat etmeğe çalışmak, yanlışların en tehlikelisidir. Çünkü artık o yanlış olmaktan çıkarılmış, ona doğruluk, gerçeklik elbisesi giydirilmiş olduğundan o her zaman yapılacak doğruluğa büründürülmüştür. Onu savunanlar yeniden uygulanmasını ve kolayca savunma yeteneğini öğrenmiş olacaklardır. Örneğin 'o yanlıştı, ama o şartlarda öyle yapmak gerekirdi' gibi savunmalar çok tehlikelidir. İlk zamanlarda yanlış idiyse, ona her zaman yanlış demekten kaçınmamak gerekir.

“Kur'ân'a Göre Araştırmalar" kitabımda, Kur'ân'a başvurduğumuz zaman düzeltilmesi gereken $\mathrm{f}_{\imath} k \mathrm{~h}$ hükümlerinin birkaçını burada maddeler halinde sıralamakla yetineceğim. Açıklamaları kitaplarımdadır

1. Boşanma erkeğin elinde değildir, mahkemededir.

2. İstemesi hâlinde kadının da boşanma hakkı vardır; mahkemededir.

3. Kur'ân'da kadını dövme yoktur.

4.Kur'ân'da zımmîlik (müslümanların idâresinde müslüman olmayanların azınlık olarak yaşamaları durumu) yoktur; cizye, savaş tazmînâtıdır.

5. Kur'ân'da mi'raç olayı yoktur.

6. Kur'ân'da kadere îman yoktur.

7. Kur'ân'da erkek, kadından daha erdemli değildir.

8. Kur'ân'da şefâ'at yoktur.

9. Kur'ân'da kadınların çalıştıkları kendilerinindir.

10.Kur'ân'da boşanmanın tek nedeni geçimsizliktir.

11.Müslüman bir kadın, müslüman olmayan bir erkekle evlenebilir.

12.Kur'ân'da idâre sistemi, 'danışma' (şûrâ)dır.

13.Kadınlar hayızlı iken namaz kılar, oruç tutabilirler.

14.Hür ve cariye kadınların kıyafetleri Kur'ân'da aynıdır.

15. Farz namazların kazası yok, tövbeleri vardır.

16.Abdestsiz, gusülsüz, hayızlı olarak Kur'an tutulur ve okunur. ${ }^{7}$

17. Naylon çorap üzerine meshedilir.

${ }^{7}$ Her ne kadar kitaplarımda bu maddeler açıklanmışsa da Diyânet İşleri Başkanlığının 2001 yılı takviminin 3 Aralık tarihli yaprağının arka sayfasında "Kadına hayızlı halinde namaz kılmak, oruc tutmak, Kur'ân okumak, Kur'ân'a el sürmek, mescitlere gitmek, tavaf etmek haramdır" denmektedir. Diyanetin yayınları gerçek ilim adamları tarafından kontrol cdilmediği için, burada hayızlı kadına haram saydıkları hususlar, yalan nakle dayanan yanlışlardır. Açıklaması için bak: Hüseyin ATAY, Kur'ân'a Göre Araşırmalar, I-III, s. 36 
18.Farz namazlardan önce ve sonra kılınan sünnet namazlar nafile namazdır, onları farzlardan önce ve sonra kılmaya gerek olmayıp insanın hiçbir işi olmadı̆̆ı, boş zamanlarını değerlendirmek için nafile olarak kılınmaları en doğrusudur.

19.Sıkıntılı, dar zamanlarda, öğle ile ikindiyi, akşam ile yatsı namazlarını öncelikli ve sonralıklı olarak birlikte bir arada kılmak doğru olur. Öncelikli demek, ikindiyi öğle ve yatsıyı akşam vaktinde sırasına göre kılmak demektir.

20.Cünüp iken su yıkanamayacak derecede soğuk ise veya yıkanıp hemen soğuğa çıkma zorunluluğu varsa, yalnız abdest alınır, namaz kılınır, normal zaman gelene dek bu durum, bu şekilde devam eder. Abdest almak için gereken su varken teyemmüm edilmez.

21. Kadınların baş açık Kur'ân okumaları, namaz kılmaları câizdir. Başı örtmek, namazla ilgili değildir.

22. Teyemmüm su hiç kullanılmadığı zaman alınır. Hem gusül, hem de abdest yerine geçer. Su da toprak da yoksa, abdestsiz ve teyemmümsüz namaz kılınır.

23. Güneşin doğuşuna kadar sabah namazı kılınabileceği gibi, güneşin doğuşuna 15 dakika kalana kadar sahur yenilebilir.

24. Trenlerde, dağ başlarında, içilmeye insanın gönlü çekmeyen ama temiz olan sularla, ağza, burna su vermeden abdest alınabilir. Kur'ân'da ağız burun söylenmiyor.

25. Boşanmada iki şâhit şarttır; nikâhta olduğu gibi.

26. Kadın güvende olduğu sürece, yalnız başına seyahat etmesi caizdir.

27. Hayızlı kadın hac tavafı yapabilir.

28. Hz. Îsâ ölmüştür; son zamanlarda gelmeyecektir.

29. İslâm'da Mehdî inancı yoktur.

30. İslâm inancında Deccâl yoktur. Ama her ulusu kötü duruma düşüren, fâsık, fâcir, deccâller zaman zaman çıkabilir.

31. Kadınlar, eğe kemiğinden yaratılmamıştır.

32. Kur'ân'da eşcinselliğin hükmü bulunmaktadır.

33. Gusülde ağza, buruna su vermek gerekmez.

34. Kur'an'da nesih yoktur.

35. Teheccüd namazı yok, yerine Kur'ân okumak vardır.

36. Oruçta kefâret yoktur.

37. Kur'ân'da 'İslâm' ve 'îmân' ayrıdır.

38. Namazlarda sehiv secdesi yoktur. Namaz fâsit ise iâde edilir.

39. Tövbe, kefâretten daha büyük cezâdır.

40. İslâm'ın din bilgisi kaynağı akıl ve Kur'ân'dır.

41. Sakal bırakmak, namaz sünneti gibi dini sünnet(peygamberin sünneti) olmayıp tabiî sünnettir.

42. Hz. Peygamber sekiz rek'atten fazla terâvih namazı kılmamıştır.

43. İslâm'ın şartı beş deģil, Kur'ân'ın bütün amelî emirleri içinde farz olanlar İslâm' in şartıdır. 
44. Kur’ân'da hırsızın elini kesmek, hırsızlığı önlemek anlamındadır.

45. Kur'ân'a gidip fıkhın, tasavvufun, kelâmın hüküm ve kurallarını gözden geçirip değiştirmenin temel kuralı şudur: Günümüzün şartlarına göre âyetleri insanın, toplumun yararına yorumlamaktır. Kur'an'ın amacı insanın yararıdır.

46. Kur'ân'ın âyetlerini yeniden hukûkî, siyâsî, dînî, idârî ahlâkî vb. olarak yeniden sınıflandırmak doğru olur.

\section{7. İki Asırlık Emek}

İslâm dünyası iki yüz yıldan beri düşmanlara karşı yenilenmenin sancılarını çekmektedir. Bu kadar uzun süre içinde kalkınma yönünde henüz bir adım atamadı. Bunun nedenini bilmiyor, bilmeye de çalışmıyor; çünkü bilmek de istemiyor; zira bilmek istemesi, düşünmesi demektir. Düşünmek en zor şey. Çünkü düşünürse, düşündüğünü yapmak zorunda kalacak. Oysa asalak yaşamayı, başkasından dilenmeyi rahatlık görüyor. Rahatlık, tembellik kişiliksizliktir. Halbuki düşünmek ve düşündüğünü yapmak insana kişilik, mutluluk, zevk ve huzur verir. Rahatlık, ve gevşeklikte mutluluk yoktur, hımbıllık, pörsümüşlük vardır. Böyle olan insana alay olsun diye, 'rahatlık kıçına battı' deyimi kullanılır. Kölelik rahat bir meslektir; sorumluluğu yoktur. Efendilik, başkanlık ise rahat değildir, sorumluluk ister.

İki yüz yıldan fazla bir zamandan beri, bazı bilginler, yeni bir anlayışa gitmenin gereğini anlatmaya çalışmı̧̧lar, bazı idareciler kendilerince, güya yenilik isteminde ve girişiminde bulunmuşlar. Ancak idareciler, bilginlere yardım etmemiş, herbiri bu yenilikleri kendi alanında yapmaya çalışmışlardır. Burada şunu özellikle vurgulamak istiyorum: Bilginler, idarecilerden daha samimi dini için ve milleti için sıkıntıya girmeyi bir ibadet kabul ettikleri halde, idareciler sadece milleti nasil susturup mevkilerini, taht ve sandalyelerini koruyacaklarını düşünmüşler ve şimdi de aynı tutum ve davranışsürmektedir.

Bilginlerin başarı gösterememelerinin sebeplerini şöyle sıralamak mümkündür:

a) İlk üç asırda müslümanların ortaya koydukları medeniyet dünyayı şaşırtmış derecede parlak ve göz alıcı idi. Sonra gelen on asırlık dönemdeki insanlar mirasçısı oldukları bu medeniyeti, onunla övünmenin ötesine geçip, geliştirme başarısını gösteremediler; altında ezilip kaldılar. Bugün bin yıl sonra gene onun boyunduruğunda ezilip büzülmüş, kişiliksiz olarak geçmişle kıvanç duymakla yetiniyorlar.

b) İlk üç asrın ilmî ve medenî, idârî başarılarını kutsallaştırdılar. Onları kutsayıp o başarının kaynağı olan Kur'ân'a inandıklarını dilleri ile söyledikleri halde, akıllarını kullanarak onu zamanlarına göre anlamayı gereksiz, boşuna bir emek saydılar. Nitekim Yunus Emre de 'ilim' konusuna boşuna bir 'emektir' dememiş miydi? Tasavvufçular, insanı ilimden yoksun bırakma çabasının, ilmi küçük düşürerek başardılar. Çünkü ilim insana 
kişilik, şahsiyet verir. Tasavvuf ve kurumu taklitçilik, şahsiyet düşmanlığı yapar.Böylece Kur'ân'dan, ilimden ve akıldan uzak kaldılar. Oysa ilk medeniyetin ve ilmî icatların temel kaynağı akıl ve Kur'ân idi. Bu ikisini yitirdiler. Hâlâ bulmaya da çalışmıyorlar. Çünkü müslümanlar, daha neyi yitirdiklerini bilmiyorlar. Zâten akıl gidince her şey ve Kur'ân da gider.

c) Müslümanların yenilenmelerine engel olan diğer bir sebep de İslam kültürünün, fıkhın, kelâmın, tasavvufun, hadisin çok yaygın ve baskın, tutucu, emredici(buyurgan) itaat istemiş olmasıdır. Bu kültürü eleyerek, eleştirecek kimselerin yetişmesine izin verilmemesi, biraz başını diklemeye çalışanın hapsedilmesi, sürgün edilmesi ve gerekirse öldürülmesi, başkasının zihnini köreltmiş, başını öne eğdirmiştir. Günümüzde din dışında da öyle değil mi?

d) Diğer bir neden de ilmî rekabetin kalmamasıdır. Bütün ümmet aşılmaz, geçilmez, çelik, zihnî ve resmî çitlerle birbirinden mezhep adı altında ayrılmış, herbir mezhep kendi dar alanında öncekilerin eserlerini öğrenip ezberleyip durmuşlar. Halk ile medreseliler kaynaşmış durumda olduklarından bir medreseli bilginin halkın üzerinde etkisi, devletten fazla idi. Burada sosyal işler, dînî kültürle kaynaşmış olduğundan, bir mezhepten diğerine geçmek için resmî müftü veya kadıdan yazılı izin almak gerekirdi. Böyle sıkı sıkıya kenetlenmiş çitlerle çevrili bir topluma yeni bir fikir sokmak zordu ve olmadı, hâlâ da bunca yenilgilere karşı eski ve yeni zihniyeti ve kültürü, yeni bir fikrin, anlayışın düşünme tarzını ortaya atanı ya dinsiz ya da düşman saymayı halka açık ve gizli, yazılı veya sözlü söylemekte etkili olmaktadırlar.

e) İslâm dünyasında yenilenmenin karşısına çıkan hükümetler ve idareciler, siyasilerdir; çünkü bunlar güdülecek toplum isterler. En kolay güdülecek toplum düşünmeyen toplumdur. Yeni bir fikir ortaya koyma, ancak düşünme sonucu olur. Türkiye'de dînî eğitim ve dînî olmayan modern eğitim ezbercidir, düşünmeye karşıdır. Her iki eğitim de hükümetlerin kontrolünde ve idaresindedir. Hükümetin kontrolü dışında yapılan dînî eğitim ise hem ezberci, hem taklitçi, hem baskıcı olmakta resmî okullarda, fakültelerde yapılan dînî eğitimden bir kaç kat daha gericidir, yenilenmeye karşıdır. Teknik eğitim otomasyon adam yetiştiren iki ikinin dört etmesi gibi otomasyon bilgisidir; onda düşünceye yer yoktur. Evet düşünerek bilgisayar yapılmış, ancak insan beyninin çalı̧̧masını durdurmuştur.

f) Düşünmeyi eylem haline getiren, düşünmeyi sağlayan ve geliştiren üç bilim dalı vardır: Felsefe, kelâm, ve mantık(FKM). Bunları bilmeyen ve bunları öğrenmeyen kimse ilim üretemez, düzenli düşünemez. Bir dakika önce söylediği ile, bir dakika sonra söylediği arasında çelişki olduğunu anlayamaz, kendi kendini gülünç duruma, sözüne güvenilmez konumuna düşürür. Bugün, halkımızdan çok siyasilerimizde bu apaçık görülmekte, köşe yazarları incelikle gırgır geçmeyi ihmal etmemektedirler. 
g) Dinde reform olmadan, Türkiye'de hiçbir yeni düşüncenin olamayacağı bir hakikat olarak ortada durmakta, 228 yılın (1774'ten beri) deneyimi de buna şahitli etmektedir. İlimde devrim, dinde reformdan geçer. Reformun anlamı: 'düşünerek yanlışı bırakıp daha iyiye ulaşmaktır.' Dinde yenilik ancak düşünce ile, düşünce ise doğruyu yanlıştan ayırmakla olur. Din ise doğrunun yapılmasını buyurur, yanlışın yapılmasına ceza keser. Düşünme eylemdir. Bu eylemi yapma insana şahsiyet kazandırır ve insan bu sayede sorgulamaya yiğitçe başlar.

Türkiye'de Diyanet'in Birinci Dîn Şûrâsında sunduğum tebliği, Diyanet itiraz notları ile olduğ gibi buraya almakla elli yıldan beri en resmî makamlara açıkça ulaştırdığım yenilenmenin yöntemini ve amacını ortaya koyuyorum:

\section{Dini Yenilenmenin Önündeki Ü̧̧ Engel}

İslâm dünyasında ve Türkiye'de dînî yenilenmeye, ıslâhata (reforma) gitmeye üç dînî engel vardır:

a) Birincisi hadis uydurması, mevzu ve zayıf hadis kültürüdür. Zayıf hadis en büyük engeli teşkil ediyor. Zira mevzu hadis engelini aşmak kolay, ama zayıf hadis engelini aşmak daha zordur. Çünkü ona meşruluk tanınmıştır. Mevzu ve zayıf hadis dini istismarın ilk kaynağı ve Kur'ân'dan yüz çevirmenin ilk adımıdır.

b) İkincisi tasavvuf ve tarikat kültürüdür. Bunlar Allah adına konuşurlar, kendi sözlerini şer̂̂'attan üstün tutarlar. Bunu iki yolla yaparlar: Biri yorum ve tevil yapmak, diğeri de Kur'ân'ı ancak kendilerinin anlayacağı yönündeki iddiaları. İnsanların düşünmesine yasak koyarlar; böylece insanların zihinlerini dondurur, müritlerini köle gibi kullanırlar. İnsanı ölü, şuursuz duruma sokarak teslim alırlar.

c) Üçüncüsü fıkıh taklitçileridir. Bunlar fıkhı şeriat, yani Kur'ân gibi yanılmaz ve değişmez sayarlar, fıkhı Kur'ân gibi nass kabul ederler. Fıkha aykırı bir fikir, anlayış ortaya koymayı dinden çıkmakla suçlarlar.

Altıncı asırdan (Fahruddîn-i Râzî) sonra kelam, fıkıh âlimleri, kadıların eline geçmiş, kadılar hem fıkıhçı hem de kelâmcı olmuşlardır. Abdullah bin Ömer Beydâvî, Abdurrahman Î́î başta gelir. Hem kadı, hem kelamcı Kemâl bin Humâm da öyledir. Mes'ûd bin Ömer Taftazânî'yi (1389) sırf kelâmcı görüyoruz.

Bu üç mezhebin $(a, b, c)$ yanına kelamcıları da her birisini destekleyici olarak zikretmek bir dereceye kadar doğru görülse de gerçek kelamcıları, yani bu üçünün etkisinden kurtulmuş, uzak kalmış, sırf kelam ilminde ihtisas yapmış olanları ayrı tutmak gerekiyor. Muhakkikin(gerçek uzman) kelamcıların bu ưç mezhebe karşı başarı sağlayamamaları, öncekilerin hem cahil halka, hem de idareye, devlete dayanmış olmalarıdır. Devletler ve hükümetler bunları desteklememişlerdir. Çünkü bu üç mezhep ve bunlara 
destek veren hem fıkıhçı hem de kelamcı olanlar, insanları mutlak itaate, köleliğe, düşüncesizliğe körü körüne boyun bükmeğe özendirmiş, alıştırmış ve böylece dünyalarını cehennem etme yerine, insanlara cenneti vaat etmişlerdir.

Hadisçiler Kur'ân yerine hadis okurlar. Tarikatçılar, Kur'ân yerine efendilerinin düzdükleri 'evrâd' denilen hutbeleri okurlar; taklitçi fıkıhçılar fıkıh kitaplarını okurlar. Kur'ân'ı mezarlıkta dua olsun diye okurlar.

$\mathrm{Bu}$ üç yolcu kendi adlarına konuşmazlar. Hadisçiler peygamber adına, tasavvuf ve tarikatçılar Allah adına, fıkıhçılar, mensup oldukları mezhebin imamı adına konuşurlar. Böylece insanları kendilerine daha kuvvetli bağlarlar; hükümetler de bunlara iltifat eder ve milletleri kuzu kuzu yönetirler. Ama dünya milletleri içinde, ilimde, teknikte, ahlâkta, adâlette, kişilik sahibi olacak hür düşünmede, insanlık haklarını, insanca yaşayamamakta en geride olduklarına razı olurlar. Sanırlar ki böylece öteki dünyadaki cenneti kazanırlar. Daha bilmezler ve kendilerine öğretilmez ki, Kur'ân'ın isteği ve amacı dünyaya adaletle hükmeden, bilgin ve bilgi sahibi, Allah'dan başkasına boyun bükmeyen, tapmayan, el ve avuç açmayan insan olmaktır ve cenneti bu gibi insanlara vaat etmiştir. Başkasına boyun bükene, beline kadar eğilene, Allah'dan başka efendi, ağabey edinene Allah diyecek ki; 'Beni kullanarak boyun eğdiğin, kul köle olduğun efendine git!' Kur'ân'a inanan bunu böyle bilir ve ona göre davranır. Kur'ân'ı rehber ve doğru yol göstergesi olarak fiilen kabul edip uygulamayan, Kur'ân'ın söz verdiği nimetlere ulaşamaz.

Şimdi, müslümanları bu üç yolculuktan kurtarmak için ne yapmak gerekir; çünkü bu üç yol patika yoludur; kasisli, insanı sürçtürür. İnsanları gerçeklere ulaştıran, hem de kısa yoldan ulaştıran Allah'ın yolu, düzdür, çukuru, engeli olmayan, müstakîm bir yoldur. İște bu, Kur'ân'ın yoludur. Dinde yenilik(reform) yapmak insanları bu üç yoldan çevirip Kur'ân yoluna çevirmekle olur. onun için elli yıldır Kur'ân'ı yeniden anlamaya çağırıyorum.

Bu üç engeli (yolu) aşmak için üç bilim kolu vardır: a) Felsefe, b) Kelâm, c) Mantık (FKM).

a) Felsefe fikir üretir, yenilikler, yeni anlayışlar, değişik düşünceler ortaya koyar.

b) Kelâm, felsefenin ürettiklerini değerlendirir.

c) Mantık ise düşüncelerin, önermelerin birbiriyle ilişkilerini,tutarlı, tutarsız çelişkili olup olmadıklarımı, sebep netice iliş̧ilerini inceler ve ona göre değerlendirir. Bunlarla Kur'ân'a gidilirse çıkı̧ yolu bulunur. Islâhât(reform) yapılır ve yepyeni bir İslâm medeniyeti doğar. 